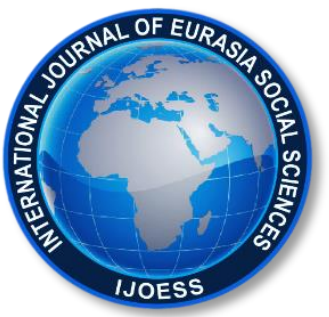

International Journal of Eurasia Social Sciences

Vol: 11, Issue: 40, pp. (493-518).

Article Type: Research Article

Received: 28.12.2019

Accepted: 06.05.2020

Published: 07.06.2020

\title{
THE EFFECT OF OPERATING RATIOS ON FIRM VALUE: AN APPLICATION IN EUROPEAN AIRLINES *
}

\author{
Faruk DAYI \\ Assist. Prof. Dr., Kastamonu University, Turkey, fdayi@kastamonu.edu.tr \\ ORCID:0000-0003-0903-1500 \\ Tolga ULUSOY \\ Prof. Dr., Kastamonu University, Turkey, tulusoy@kastamonu.edu.tr \\ ORCID:0000-0002-4365-0877
}

\begin{abstract}
Firms should use their assets efficiently to increase their profit. There are many methods to evaluated the productivity of firms' activities. Ratio analysis is widely used to analyze productivity for financial performance. This study is used activity ratios to evaluate the financial productivity of airlines. Activity ratios are used the productivity of firms' assets, receivables, payables, inventories and fixed assets. As firms use their assets productively, their profit increases. Firms' high performance can raise their stock value, which in turn, increases their value. In this study, it is aimed in productivity in terms of activity ratios for Airlines. In addition, it is investigated the effect of activity ratios on firm value in this study. The 7-years (2010-2016) data of the top 10 airlines operating in Europe are used in the implementation. Asset turnover, inventory turnover, accounts receivables turnover, financial leverage ratio and stock price variables are analyzed using the method of panel data. According to analysis of results, firm value is positively affected by accounts receivables turnover and asset turnover, and negatively affected by inventory turnover and financial leverage ratio. As the financial productivity increases, the value of the firm increases.
\end{abstract}

Keywords: Airlines, operating ratios, firm value, productivity, panel data

\footnotetext{
"This study was presented at the "International Finance and Banking Conference FI BA 2019" in Romania on 28-29 March, 2019.
} 


\section{INTRODUCTION}

Financial development for firms' economic activity has debated for years (Filer et al., 2000: 1). In the growth and development of firms, assets must be used effectively and efficiently. Firms want to increase their performance for productivity (Bartz-Zuccala et al., 2018: 503). Efficiency is not that firms cut costs and produce cheap goods. If the firms achieve maximum output with minimum input, the efficiency of the firm is increasing. Increasing efficiency, financial analysis should make by firm. Financial analysis is used to assess firms' financial situation and performance. A financial analysis is necessary to examine the financial performance. As a simple definition, financial analysis is the analysis of income statement and balance sheet data by various analysis methods. Firms analyze the financial statements of previous years to determine their current financial position prior to making any financial planning, which enables them to obtain fund needed to achieve their goals.

This study investigates the performance of firms operating in the civil aviation sector, which has become increasingly significant in the global economy and bolsters its total assets every years. Because operating performance is related to firm value in stock market (Hamadi \& Bassil, 2015: 598-601). To this end, the effect of activity ratios on the market value of the Top 10 airlines operating in Europe was analyzed. We believe that the results of this study will contribute significant to the literature.

\section{LITERATURE}

Firms should use their assets effectively to achieve their targets. In addition, firms need previous years financial data to make their future plan. Therefore, assessing firms' financial performance play a significant role in financial analysis (Bayburt, 2007: 578). Financial analysis is generally performed using financial statements analysis technique, one of the most widely used of which is ratio analysis (Karadeniz et al., 2014: 131).

Ratio analysis is performed calculating mathematical ratios on interrelated accounts in financial statements in four categories; liquidity, activity, financial structure and profitability (Akdogan \& Tenker, 2007: 640). Liquidity ratios are used to evaluated the liquidity status of firms. Financial structure ratios are used to evaluated the resources structure of firms. Profitability ratios are used to evaluated for financial performance. Activity ratios are used to evaluated operating performance for firms. Because operating performance is very important for both operating and financial success. The more efficient the activities of firms, the higher the performance of firms. Therefore, firms should use their assets productivity and efficiently.

This study analyzes the effect of activity ratios on airlines firms' market value. Airlines have high-cost aircrafts, hence high-cost asset, which means that they have a small number of but expensive aircraft. Therefore, they should use their assets effectively to achieve their financial goals. Airlines firms have high amount of assets. Using efficiently of assets is closely related to the degree of leverage of the activity. When assets are not used effectively, the assets can be reduced. Because firms with operating leverage can make high marginal profit. The purchase of high-cost assets increases their short and long-term liability. Increasing the liability, the cost of 
capital and the level of financial risk increases. However, they keep low-cost inventory and sell tickets in advance or in short-term installments, reducing their debt collection period and increasing their liquidity. Firms' financial position should be assessed using activity ratios in order to analyze whether they use their assets effectively.

\section{LITERATURE REVIEW}

The number of studies on the relationship between airlines' activity ratios and market value are very limited. Because, related with the effect of operating ratios on firm value has not got in the literature. Therefore, it is explained research on ratio analysis method and airlines' financial and operational performance. Related studies in the literature are also included in this section.

Pineda et al. (2018) propose a model to improve the financial and operational performance of airlines. Various methods are used in the analysis as MCDM, Data Mining and DANP. They found that the current model can be used by airlines to achieve financial efficiency. Dayi and Ulusoy (2018) used various ratios such as asset turnover, accounts receivable turnover and inventory turnover ratios to assess the financial performance of 19 international airlines. The Minimum Spanning Tree Approach is used in the application. According to results of analysis, Turkish Airlines has high profitability, assets and revenues. Sakiz and Unkaya (2018) investigated the risk of bankruptcy of Turkish Airlines (THY) to assess airlines' financial and operational performance. All calculated data of THY shows that airline is in a good financial condition terms of bankruptcy risk. Seufert et al. (2017) use variables (capital, staff, etc.) to evaluated efficiency and productivity of airlines in the World in the period of 2007-2013. European airlines are more successful than the others for operational efficiency and productivity.

Omrani and Soltanzadeh (2016) used the NDEA (Network Data Envelopment Analysis) method to assess Iranian airlines' performance. The results obtained from the model enabled the determination of sections with lower efficiency. Teker et al. (2016) assessed the financial performance of 20 major international airlines. It is stated that financial performance measurement based on total income or profitability is weak and that other indicators can be expanded by Including other indicators. Saranga and Nagpal (2016) evaluated Indian airlines' operational performance in terms of efficiency. According to the results of the analysis, some structural and regulatory factors have an undesirable effect on airline performance, but low cost carriers in India have achieved significant operational efficiency. Miranda et al. (2016) investigated to show efficiency for difference performance factors as low cost and airline carries. They have used the method of Multi Criteria Decision Making. Analysis results show that would measure efficiency for companies.

Wanke et al. (2015) used the TOPSIS and MCMC generalized linear mixed models to assess Asian airlines' operational performance. The findings show that costs, ownership type, market positioning is important on efficiency. Arjomandi and Seufert (2014) chose comparing performance of 48 airlines in six different region period of 2007-2010. Results show that technically efficiently airlines are from China and North Asia and many 
airlines in Europe have got the best environmental performance. Tretheway and Markhvida (2014) examine the sustainability levels of airline companies in the long term. Airlines has got high fixed assets and cost. According to analysis results, they should reduce their marginal cost and to use their assets effective. Omurbek and Kinay (2013) used the TOPSIS method to analyze the performance of two airlines operating in Turkey and Germany. The performance indicators and weights of the two airlines were evaluated by using TOPSIS method. It was stated that one of the companies performed better than the other.

Coli et al. (2011) investigate that improving efficiency for airlines via Data Development Analysis and Stochastic Frontier Analysis. Method of SFA gives more successful results than DEA. Assaf and Josiassen (2011) assessed British airline companies' performance using data envelopment analysis. In the study, it is stated that the increase in oil prices and the factors of severe market competition are among the determinants of potential inefficiency. Malighetti et al. (2011) have investigated the factors that have an impact on the value of airlines and airports. The analysis is included 24 airport and 87 airlines in the World. Although the age of airline companies and the number of routes have a negative impact on the market value, the market value for lowcost companies is statistically higher than the other.

Homsombat et al. (2010) evaluated the financial and operational performance of airline firms operating in North America. It is stated that the efficiency levels of the airlines are related to the over all economic cycle, the efficiency levels of the Airlines as total factor productivity. Barros and Peypoch (2009) examined the operational performance of airlines operating in Europe using Data Envelopment Analysis. As a result of Regression analysis, it was stated that population and flight networks played an important role in the effectiveness of airlines. Barbot and Sochirca (2008) have searched difference airlines productivity and efficiently. According to analysis, they do not suggest DEA analysis for efficiency and effectiveness every time. Schefczyk (1993) researches operational performance of 15 international airlines with analysis of DEA. The analysis results show that the higher airlines have operational performance, the higher they have profitability.

\section{MATERIAL AND METHOD}

The aim of this study was to analyzed the effect of the operational performance of airlines operating in Europe on their market value. It was made for the first time in the literature. Investigation of the impact of financial performance on the value of the firm is expected to contribute significant to the literature. The evaluation of the financial efficiency of the firms with their operational ratios was made in trade and industrial companies before. For this reason, the study sample consisted of airlines firms. The 7-year (2010-2016) data of the top 10 airlines operating in Europe were used. The 10 biggest airlines in Europe, the names, origins of the airline firms and passengers numbers (in 2016) are given in Table 1 (CNNTURK, 2019): 
Table 1. List of Airlines

\begin{tabular}{clcc}
\hline Number & Airlines & Country & $\begin{array}{c}\text { Passenger Numbers } \\
\text { (million) }\end{array}$ \\
\hline 1 & Lufthansa Group (Lufthansa, Austrian, Swiss, Eurowings) & Germany & 117,4 \\
\hline 2 & Ryanair & England & 101,4 \\
\hline 3 & IAG (British Airways, Iberia, Vueling, Aer Lingus) & England - Spain & 94,9 \\
\hline 4 & Air France - KLM (Air France, KLM, HOP Transavia) & France & 87,4 \\
\hline 5 & Easyjet Airlines & England & 74,5 \\
\hline 6 & Turkish Airlines & Turkey & 62,8 \\
\hline 7 & Aeroflot Group (Aeroflot, Rossiya, Pobeda) & Russian & 43,4 \\
\hline 8 & SAS Group (Scandinavian Airlines) & Sweden & 29,4 \\
\hline 9 & Norwegian Airlines & Norway & 29,3 \\
\hline 10 & Air Berlin Group (Air Berlin, NIKI) & Germany & 28,9 \\
\hline
\end{tabular}

Reference: https://www.cnnturk.com/dunya/avrupanin-en-buyuk-10-hava-yolu-sirketi?page=8

Lufthansa Group carried 117.4 milion passengers with the highest passengers in the Europe in 2016. As Ryanair offers a cheap ticket price, they are second place in the Europe. It carried 101.4 million passengers in the 2016. Turkish Airlines carried 62.8 million passengers and it is sixteenth in the Top 10. SAS Group, Norwegian Airlines and Air Berlin Group have carried lower number of passengers than the Top 10. Berlin Group is 28.9 million passengers with the lowest passengers in the Top 10.

There are many ratios in the literature, evaluating for airlines financial productivity as like current assets turnover, fixed assets turnover, etc. However, using activity ratios suitable for sectors in which firms operate is vital to the success of research. Dayi and Esmer (2017) assessed the financial performance of airlines using accounts receivable turnover, inventory turnover, net profit margin, return on assets (ROA) and return on equity (ROE). It is stated that increased the revenues in airlines, their receivables is increasing so much. Inventory turnover is decreasing that airlines have fewer inventories by previous year. Therefore, these variables are very important for airlines financial productivity. Unlike other studies, a model was created from the most used activity ratios in this study. Therefore the ratios that elicit information on the airlines' activity were used in this study. Table 2 shows the codes, data types, frequencies and data sources of variables in the Model.

Table 2. Variables and Data Set

\begin{tabular}{lcccc}
\hline Variables & Codes & Types & Frequency & Data Sources \\
\hline Stock Price & P & Dependent & Daily & Yahoo Finance \\
\hline Assets Turnover & AT & Independent & Annual & Financial Statements \\
\hline Accounts Receivable Turnover & ART & Independent & Annual & Financial Statements \\
\hline Inventory Turnover & IT & Independent & Annual & Financial Statements \\
\hline Financial Leverage & FL & Independent & Annual & Financial Statements \\
\hline
\end{tabular}

2006-2016 data was going to be used in the implementation; However, 2009 data was excluded as the financial statements of that year were negatively affected by the 2008 global financial crisis is stated that by Isik and 
Kiraci (2012). Therefore, data set includes 2010-2016 periods. Asset turnover, accounts receivable turnover, inventory turnover and financial leverage ratio were calculated using independently audited financial statements. The closing price of the stock on the last day of the fiscal year was taken as the stock price. It was taken from related stock exchange. Because, the last closing price shows the value of company in that year. The success of the airlines at the end of the operating period is expected to reflect on the price of the stock. Financial performance increases as airlines use their assets efficiently. Thus, the financial performance of the airlines is expected to have a positive effect on the stock value of the stocks.

The asset turnover ratio is calculated by dividing net sales by average total assets and shows the productivity use of firm assets. The higher the asset turnover ratio, the more productivity the firm uses its assets. Firms have low assets should have high asset turnover rate. What is important is to achieve high efficiency, using fewer assets. The accounts receivable turnover ratio indicates the number of times the net sales meet accounts receivables. The higher the accounts receivable turnover ratio, the better it is, because it shows that the firm collects its receivables quickly. The collection of receivables is important for the cash cycle. If the receivables collect late, the firms may suffer cash burn. As more sales are made in advance, the firms can have more cash. Because they will reduce their receivables. The inventory turnover ratio shows the number of times inventory is sold or used in a year. The higher the inventory turnover ratio, the shorter the period that the firm converts its inventory into cash or receivables. Furthermore, firms want to convert inventory into cash. Since airlines have low cost of inventories, their inventory turnover ratios are not expected to be very high. The average collection period and inventory cycle time were not included in the analysis, as they would have a high correlation with the accounts receivable and inventory turnover ratios. There is a significant relationship between financial leverage ratio and profitability (Cakir \& Kucukkaplan, 2012: 81). Financial leverage is an important indicator of the efficiency of assets. As borrowing increases, firms pay more interest. When the expenses increase, the profit of the firms decreases. Therefore, financial leverage is used the model for evaluating financial performance about liabilities.

Panel data consists of a combination of multiple horizontal and time sections such as households, companies and countries (Baltagi, 2005: 1). Several horizontal and vertical sections require panel data analysis. Because it is not possible to use econometric methods other than panel data analysis in case of more than one crosssection in time series. The formula used in panel data regression analysis is as follows (Baltagi, 2005: 11):

$$
y_{i t}=\alpha+X^{\prime}{ }_{i t} \beta+u_{i t} i=1, \ldots \ldots N ; t=1, \ldots \ldots T
$$

$i$ is the number of firms, $t$ is the time series, $u_{i t}$ is the coefficient of error, $\alpha$ is the constant, $X^{\prime}{ }_{i t}$ is the it number of observations and $\beta$ is the coefficient of explanatory variables (Guris, 2018: 7). There are several panel data analysis methods, the most common of which are fixed effects, random effects, pooled regression and stochastic parameters (Green, 2010: 386-387). There are also balanced and unbalanced panel data models (Baum, 2006: 46-51). Unbalanced panel data analysis is used when a dataset has missing data on some years (Tatoglu, 2013: 1). Hausman test is used to decide which method to use in panel data analysis. Hausman test is 
used to decide which estimators to use in panel data analysis (Tatoglu, 2018: 184). The dependent variable has missing data for several years because one of the firms in the sample started trading on the stock market after 2010. Therefore, unbalanced panel data method was used. The model of the study is as follows:

$$
P_{i t}=\alpha+\beta_{1} A T_{i t}+\beta_{2} A R T_{i t}+\beta_{3} I T_{i t}+\beta_{4} F L_{i t}+u_{i t}
$$

Stock price is the dependent variable while asset turnover, accounts receivable turnover, inventory turnover and financial leverage ratio are the independent variables. In order to prevent differences in stock prices from affecting the model, their logarithms were used. As the model is unique and different the others, it is expected to make significant contributions to literature.

\section{FINDINGS}

It is presented firstly the descriptive statistics of the variables in this section. The analysis results of Hausman, Breusch Pagan and Panel Data Random Effects test are given later. Firstly, it has been analyzed the descriptive statistic. Results of analysis are given that Table 3.

Table 3. Descriptive Statistics

\begin{tabular}{lcccc}
\hline Variables & Mean & Std. Dev. & Min. & Max. \\
\hline Price & 1.45 & 0.98 & 0.23 & 3.24 \\
\hline Asset Turnover & 67.28 & 554.46 & 0.39 & 4.64 \\
\hline Accounts Receivable Turnover & 19.90 & 21.26 & 3.67 & 99.01 \\
\hline Inventory Turnover & 69.74 & 57.46 & 8.06 & 288.94 \\
\hline Financial Leverage & 0.77 & 0.24 & 0.43 & 2.06 \\
\hline
\end{tabular}

The firms' stock prices range from 0.23 to 3.24 , asset turnover ratio from 0.395 to 4.64 , accounts receivable turnover ratio from 3.67 to 99.01, inventory turnover rate from 8.06 to 288.94 and financial leverage ratio from 0.43 to 2.06 , showing that the ranges of the activity ratios are high. Stock price has average is 1.45 . Because it has taken logarithm. If the logarithm had not been taken, it would have a negative impact on the model as there would be a lot of differences between the prices. Asset turnover average is very high. Assets can use efficiently. Efficiently using assets increases the liquidity and profitability. Accounts receivable turnover is low. It is useful for firm this rate is high. The high turnover rate of the receivables increases the rate of converting the receivables of the firms into cash. Inventory turnover average is normal. Because the service firms do not have high inventory. Therefore the rate is high. Since they have not got high stock. Financial leverage ranges from 0.43 to 2.06 and its average is \%77. Firms operate with an average of $23 \%$ of the equities. Firms have more liabilities than equity. As the borrowing increases, the amount of interest paid increases. Furthermore, the extreme liabilities increase the financial risk.

Hausman Test is used to decide whether to use fixed effects or random effects in panel data analysis. Hausman Test has been analyzed and Table 4 shows the Hausman Test results. 
Table 4. Hausman Test Results

\begin{tabular}{lcccc}
\hline & $\begin{array}{c}\text { (b) Fixed } \\
\text { Effects }\end{array}$ & $\begin{array}{c}\text { (B) Random } \\
\text { Effects }\end{array}$ & b-B & S.E. \\
\hline Asset Turnover & .0002204 & .0002336 & -.0000132 & .0000234 \\
\hline Accounts Receivable Turnover & .0126165 & .0137277 & -.0011112 & .0018362 \\
\hline Inventory Turnover & -.0017042 & -.0018660 & .0001618 & .0003165 \\
\hline Financial Leverage & -.5127839 & -.5268744 & .0140905 & .0301479 \\
\hline Prob >chi2 $=0,9762$ & & & & \\
\hline
\end{tabular}

According to the Hausman test results, the null hypothesis (fixed effects) is rejected and alternative (random effects) is accepted ( $p>0.05)$, which means that the random effects model should be used. Breusch-Pagan test is used to decide which pooled least squares model to use with the random effects method. Table 5 shows the Breusch-Pagan test results.

Table 5. Breusch-Pagan Test Results

\begin{tabular}{l|l|l}
\hline & \multicolumn{1}{|c}{ Var } & \multicolumn{1}{c}{ st = sqrt(var) } \\
\hline Price & .9720658 & .985934 \\
\hline $\mathrm{e}$ & .0330350 & .1817555 \\
\hline $\mathrm{u}$ & .8496049 & .9217401 \\
\hline & chibar2(01) $=147.38$ Prob $>$ chibar2 $=0.0000$ \\
\hline
\end{tabular}

According to Breusch-Pagan Test results, Prob. value is smaller than 0.05. Therefore, the random effects model is used. Furthermore, panel data analysis for random effects made and Table 6 shows the results of the panel data analysis.

Table 6. Panel Data Random Effects Results

\begin{tabular}{lcccc}
\hline $\begin{array}{l}\text { Number of Observations }=67 \\
\text { Number of Airlines }=10\end{array}$ & R-sq: 0,4352 & \multicolumn{2}{l}{ Wald chi2 $(5)=28.71$ Prob $>$ Chi2=0.0000 } \\
\hline Price & Coefficient & Std. Dev. & $\mathbf{z}$ & P>z \\
\hline Asset Turnover & .0002336 & .0000631 & 3.70 & 0.000 \\
\hline Accounts Receivable Turnover & .0137277 & .0042071 & 3.26 & 0.001 \\
\hline Inventory Turnover & -.0018660 & .0008478 & -2.20 & 0.028 \\
\hline Financial Leverage & -.5268744 & .1319500 & -3.99 & 0.000 \\
\hline Constant & 1.7172740 & .3117933 & 5.51 & 0.000 \\
\hline
\end{tabular}

Panel data random effects result shows that the model is meaningful. Furthermore, all of the variables are meaningful, too. The explanatory power of model is $43.52 \%$. Asset turnover shows the efficiency of assets. When the firm uses its assets efficiently, it sells more and makes more profit, which, in turn, increases its market value. According to the results, there is a positive relationship between asset turnover and stock price. The coefficient between the asset turnover and the stock price is low. But the correlation is positive. So, the firms use their assets efficiently, their stock price can be high value. Literature is confirmed this. Ayricay and Turk (2014) found a significant relationship between asset turnover and firm value, While Karaca and Basci (2011) stated that asset turnover ratio positively affects firm value. When firms use their assets efficiently, 
sales revenues and profitability may increase. As the firm's profit increases, its equity also increases. In this case, the shareholders will want to buy the company's stock. Because, they think the company is successful. As the demand of the stock increases, the price will increase and thus the market value of the company will be increased.

If the firm, the higher the liquidity, has got the shorter the average collection period, it can have the higher its market value. There is a positive relationship between accounts receivables turnover ratio and stock value. Accounts receivables affect the firm's value by $1.3 \%$. An increase of $1.3 \%$ in the collection of receivables increases the value of the stock by $1 \%$. In other Words, when the stock price decreases by $1 \%$, the collection of receivables is expected to decrease by $1.3 \%$. As the collection of receivables increases, the liquidity of the firm increases. The increase in liquidity is expected to give up a positive impression on the financial position of the airlines.

Inventory is an important item of account for firms, and therefore, inventory turnover is an important ratio giving information about the efficiency of a firm. However, airlines are service enterprises. Therefore, they do not have as much inventory as commercial or production companies. The analysis results confirm this and show a negative relationship between inventory turnover and firm value. The coefficient is less than one percent. Although inventories are an important asset in net working capital, the rate may be insignificant as airline companies do not have inventory. Uluyol and Turk (2013) reported that inventory turnover ratio had no effect on the firm value of production companies. Therefore, there a negatively relationship between inventory turnover ratio and firm value in airlines.

The financial leverage ratio shows how much assets a firm holds relative to its equity. As the borrowing increases, the value of the firm is increasing to the optimum capital amount. The leverage effect of the debt can affect the firm value, and therefore, is included in the model. The results show a negative relationship between airline companies and financial leverage ratio. The higher the financial leverage ratio, the lower the firms' market value (up to 52\%). If firms borrow necessary, the cost of capital increases. Therefore, the value of firm is effected negatively from this situation. It is observed that airlines borrow more as their losses increase. It is thought that borrowing may have a negative impact on the market value.

\section{CONCLUSION and DISCUSSION}

Activity ratios are used to assess firms' productivity. Activity ratios are used to evaluate the firm's financial and operational performance. Activity ratios affect not only firms' performance but also their values. Making more sales with less cost, collecting receivables as soon as possible and turning them into liquidity, achieving a fast inventory turnover and taking advantage of the leverage effect of the debt increases firms' profits, which, in turn, affect their market values. This study investigated the effect of airlines' activity ratios on their firm value. 
Asset turnover shows the efficiency of assets. If asset turnover rate is high, the firms' assets used effective. Firms earn more as they make more sales. Therefore their profitability raises high. According to the results, there is a positive relationship between asset turnover and share price. The coefficient between the asset turnover and the stock price is low. The more efficiently the firms are in their activities, the more active turnover is expected, the better the company's market value. The shorter the average collection period, the higher the liquidity of a firm. There is a positive relationship between accounts receivables turnover ratio and stock value. Accounts receivables affect the firm's value by $1.3 \%$. Therefore collecting receivables positively affects the value of the firm. As firms collect their receivables, their revenues and profit increases. The more profitability firm's value can be increased. The other variable is inventory turnover is important for firms. Inventory turnover rate has meaningful in the results. But, there is a negative relationship between inventory turnover and firm value in study. This is confirmed by the fact that the inventory of airlines is small. Because, the airlines don't make to products. They do not work with inventory. The financial leverage ratio shows how much assets a firm holds relative to its equity. The results show a negative relationship between airline companies and financial leverage ratio. The higher the financial leverage ratio, the lower the firms' market value (up to $52 \%$ ). The financial leverage is effected for negatively on firm value.

The fact that airlines have high fixed-capital investment reduces the productivity use of assets. The aircraft is very expensive and airlines firms must have a lot of aircrafts growing for firm. Airlines carry as many passengers as their aircraft are equipped to carry, which positively affects the productivity of their activities. In addition, the effective use of working capital affects firms' market value. It is, Therefore, recommended that future studies assess the effect of airlines' working capital on their value.

\section{ETHICAL TEXT}

In the articles, the rules in the text below should be followed and a text similar to the text below should be added to the article under the title of ethical text.

"In this article, journal writing rules, publishing principles, research and publishing ethics rules, journal ethics rules are followed. Responsibility belongs to the author (s) for any violations related to the article. "

\section{REFERENCES}

Aeroflot Group. (2018). Reporting. https://ir.aeroflot.com/shareholders-and-investors/, Accessed 10 Dec 2018. Akdogan, N. \& Tenker, N. (2007). Finansal Tablolar ve Mali Analiz Teknikleri. Ankara: Gazi Kitabevi.

Air Berlin Group. (2018). Investor Relations. http://ir.airberlin.com/en/ir. Accessed 10 Dec 2018.

Air France KLM. (2018). Finance. https://www.airfranceklm.com/en/profil/analyst-investor. Accessed 10 Dec 2018.

Assaf, A. G. \& Josiassen, A. (2011). The operational performance of UK airlines: 2002-2007. Journal of Economic Studies, 38(1), 5-16. 
Arjomandi, A. \& Seufert, J. H. (2014). An Evaluation of the World's Major Airlines' Technical and Environment Performance. Economic Modelling, 41, 133-144.

Ayricay, Y. \& Turk, V. E. (2014). Finansal Oranlar Ve Firma Değeri İlişkisi: BisT'de Bir Uygulama. Muhasebe ve Finansman Dergisi, (64), 53-70.

Baltagi, B. H. (2005). Econometric analysis of panel data (Third Edition). England: John Wiley\&Sons, Ltd.

Barbot, C. Costa, A. \& Sochirca, E. (2008). Airline Performance in the new market context: A Comprative Productivty and Efficiency Analysis. Journal of Air Transport Management, 14, 270-274.

Barros, C. P. \& Peypoch, N. (2009). An evaluation of European airlines' operational performance. International Journal of Production Economics, 122(2), 525-533.

Bartz-Zuccala, W., Mohren, P. \& Schweiger, H. (2018). The role of innovation and management practices in determining firm productivity. Comparative Economic Studies, 60 (4), pp.502-530.

Baum, C. F. (2006). An Introduction to Modern Econometrics Using Stata. Texas: A Stata Press Publication.

Bayburt, N. (2007). Isletmelerde Performans Degerlendirmenin Onemi ve Performans Gostergeleri Arasındaki Iliskiler. Sosyal Siyaset Konferansları Dergisi, 53, 577-592.

Cakir, H. M. \& Kucukkaplan, i. (2012). Isletme Sermayesi Unsurlarının Firma Degeri ve Karlılıgı Uzerindeki Etkisinin IMKB'de Islem Goren Uretim Firmalarında 2000 - 2009 Dönemi Icin Analizi. Muhasebe ve Finansman Dergisi, (53), 69-86.

Coli, M., Nissi, E. \& Raposelli, A. (2011). Efficiency Evaluation in an Airline Company: Some Empirical Results, Journal of Applied Sciences, 11(4), 737-742.

CNN TURK. (2019). Iste Avrupa'nın En Büyük 10 Havaolu Şirketi. https://www.cnnturk.com/dunya/avrupaninen-buyuk-10-hava-yolu-sirketi?page=1. Accessed 10 May 2019.

Dayi, F. \& Esmer, Y. (2017). Measuring Financial Performance of Airline Passenger Transport Company in European. 33rd International Academic Conference (s.60-71). Vienna: IISES, DOI: 10.20472/IAC.2017.33.008.

Dayi, F. \& Ulusoy, T. (2018). Evaluating Financial Performance with Minimum Spanning Tree Aprroach: An Application in Airlines Companies. Turkish Studies, 13(30), 89-103.

Easyjet. (2018). Investors .http://corporate.easyjet.com/investors. Accessed 10 Dec 2018.

Filer, R. K., Hanousek, J. \& Campos, N.F. (2000). Do Stock Markets Promote Economic Growth?, CERGE-EI Working Paper No.151. Available at SSRN: https://ssrn.com/abstract=1535900 or http://dx.doi.org/10.2139/ssrn.1535900

Green, W. H. (2010). Econometric Analysis. England: Pearson Education Limited.

Guris, S. (2018). Uygulamalı Panel Veri Ekonometrisi. İstanbul: Der Kitabevi Yayınevi.

Hamadi, H. \& Bassil, C. (2015). Financial Development and Economic Growth in the MENA Region. Comparative Economic Studies, 57, pp.598-622.

Homsombat, W., Fu, X. \& Sumalee, A. (2010). Policy Implications of Airline Performance Indicators Analysis of Major North American Airlines. Transportation Research Record: Journal of the Transportation Research Board, 2177(1), 41-48. 
IAG. (2018). Investor Relation. http://www.iagshares.com/phoenix.zhtml?c=240949\&p=irol-irhome. Accessed 10 Dec 2018.

Isık, E. \& Kiracı, M. (2012). 2008 Kuresel Finansal Krizin Isletmelerin Calisma Sermayeleri Uzerindeki Etkilerinin Oranlar Araciligiyla Tespiti: IMKB'de Bir Arastirma. Muhasebe ve Finansman Dergisi, 54, 157-174.

Karaca, S. S. \& Basci, E. S. (2011). Hisse Senedi Performansını Etkileyen Rasyolar ve İMKB 30 Endeksinde 20012009 Dönemi Panel Veri Analizi. Suleyman Demirel Universitesi Iktisadi ve Idari Bilimler Fakultesi Dergisi, 16(3), 337-347.

Karadeniz, E., Kosan, L. \& Kahilogullari, S. (2014). Borsa İstanbul'da Işlem Goren Spor Sirketlerinin Finansal Performansinin Oran Yontemiyle Analizi. Cukurova Universitesi Sosyal Bilimler Enstitusu Dergisi, 23(2), 129-144.

Lufthansa. (2018). Investor Relations. https://investor-relations.lufthansagroup.com/en/investorrelations.html. Accessed $10 \mathrm{Dec} 2018$.

Malighetti, P., Meoli, M., Paleari, S. \& Redondi, R. (2011). Value determinants in the aviation industry. Transportation Research Part E, 47, 359-370.

Miranda, M., Baltazar, M.E. \& Silva, J. (2016). Airlines Performance and Efficiency Evaluation using a MCDA Methodology. The Case for Low Cost Carriers vs Legacy Carriers. Open Eng., 6, 389-396.

Norwegian. (2018). Investor Relations. https://www.norwegian.com/ie/about/company/investor-relations/. Accessed 10 Dec 2018.

Omrani, H, \& Soltanzadeh, E. (2016). Dynamic DEA models with network structure: An application for Iranian airlines. Journal of Air Transport Management, 57, 52-61.

Omurbek, V.\& Kinay, B. (2013). Havayolu Tasimaciligi Sektorunde TOPSIS Yontemiyle Finansal Performans Degerlemesi. Suleyman Demirel Universitesi Iktisadi ve Idari Bilimler Fakultesi Dergisi, 18(3), 343-363.

Pineda P. J. G.,Liou, J. J.H., Hsu, C. H. \& Chuang , C. Y. (2018). An Integrated MCDM model dor improving airline operational and financial performance. Journal of Air Transport Management, 68, 103-117.

Ryanair. (2018). Investor Relations. https://investor.ryanair.com/. Accessed 10 Dec 2018.

Sakiz, B. \& Unkaya, G. (2018). Havayolu Tasimaciligi Sektorunde Iflas Riski Yapay Sinir Agları ile Airscore Tahmini. Marmara Universitesi Oneri Dergisi, 13(50), 150-172.

Saranga, H. \& Nagpal, R. (2016). Drivers of operational efficiency and its impact on market performance in the Indian Airline industry. Journal of Air Transport Management, 53, 165-176.

SAS Group. (2018). Investor Relations. https://www.sasgroup.net/en/category/investor-relations/. Accessed 10 Dec 2018.

Seufert, J. H., Arjomandi, A. \& Dakpo, K. H. (2017). Evaluating Operational Performance: A Leunberger-HicksMoorsteen Productivity Indicator. Transportation Research Part E: Logistics and Transportation Review, 104, 52-68.

Schefczyk, M. (1993). Operational Performance of Airlines: An Extension of Traditional Measurement Paradigms. Strategic Management Journal, 14(4), 301-317.

Tatoglu, F. Y. (2013). Ileri Panel Veri Analizi. İstanbul: Beta Basim Yayin Dagitim. 
Tatoglu, F. Y. (2018). Panel Veri Ekonometrisi. İstanbul: Beta Basim Yayin Dagitim.

Teker, S., Teker, D. \& Guner, A. (2016). Financial Performance of Top 20 Airlines. Procedia - Social and Behavioral Sciences, 235, 603-610.

Tretheway, M. W. \& Markhvida, K. (2014). The aviation value chain: Economic returns and policy issues. Journal of Air Transport Management, 41, 3-16.

Turkish Airlines. (2018). Investor Relations. http://investor.turkishairlines.com/tr. Accessed 10 Dec 2018.

Uluyol, O. \& Turk, V. E. (2013). Finansal Rasyolarin Firma Degerine Etkisi: Borsa İstanbul (BiST)'da Bir Uygulama. Afyon Kocatepe Universitesi Iktisadi ve Idari Bilimler Fakultesi Dergisi, 15(2), 365-384.

Yahoo Finance. (2018). https://finance.yahoo.com/ . Accessed 10 Dec 2018.

Wanke, P., Barros, C. P. \& Chen, Z. (2015). An Analysis of Asian Airlines Efficieny with two-stage TOPSIS and MCMC Generalized Linear Mixed Models. Int. J. Production Economics, 169, 110-126. 


\section{FAALIYET ORANLARININ FIRMA DEĞERI ÜZERINE ETKISI: AVRUPA HAVAYOLU FIRMALARINDA BIR UYGULAMA}

öz

Firmaların karını ve karlıığını artırmak için varlıklarını etkin ve verimli kullanmaları gerekmektedir. Faaliyetlerin verimliliğini değerlendirmek için literatürde kullanılan birçok yöntem vardır. Oran analizi yöntemi finansal performansın değerlendirilmesinde sıkça kullanıldığı görülmektedir. Bu çalışmada faaliyet oranları ile havayolu firmalarının verimliliklerini değerlendirilmektedir. Faaliyet oranları, firmaların varlıklarının, alacaklarının, borçlarının, stoklarının ve duran varlıklarının verimliliklerinin değerlendirilmesinde kullanılmaktadır. Firmalar varlıklarını etkin ve verimli kullandıklarında karları ve karlılıkları artmaktadır. Böylece firmanın faaliyetlerinin performansı, hisse senetlerinin fiyatına yansıyarak, firmanın değeri yükselebilmektedir. Bu çalışmada firmaların sıkça kullandıkları faaliyet oranlarının firma değeri üzerine etkisi incelenmiştir. Uygulamada Avrupa'da faaliyet gösteren en büyük 10 havayolu şirketinin 2010-2016 dönemine ait 7 yıllık verileri kullanılmıştır. Aktif devir hızı, stok devir hızı, alacak devir hızı, finansal kaldıraç oranı ve hisse senedi fiyatı değişkenlerine ait veriler panel veri yöntemiyle analiz edilmiştir. Firma değerinin, alacak devir hızı ve aktif devir hızından pozitif yönde; stok devir hızı ve finansal kaldıraç oranından negatif yönde etkilendiği tespit edilmiştir. Finansal verimlilik arttıkça, firmanın değeri de artmaktadır.

Anahtar Kelimeler: Havayolu şirketi, faaliyet oranı, firma değeri, verimlilik, panel veri. 


\section{Giriş}

Firmaların ekonomik faaliyetlerinin geliştirilmesi konusu yıllardır tartışılmaktadır (Filer vd., 2000: 1). Firmaların büyümesi ve gelişmesi için varlıkların etkin ve verimli kullanılmasıyla mümkündür. Firmalar verimliliklerini artırarak finansal performanslarını artırmak isterler (Bartz-Zuccala vd., 2018: 503). Verimlilik, firmaların maliyetleri düşürmesi ve ucuz mal üretmesi değildir. Firmalar minimum girdi ile maksimum çıktı elde ederlerse, firmaların verimliliği artmaktadır. Verimliliğin artması için firmaların finansal analiz yapması önerilmektedir. Finansal analiz, firmaların finansal durumu ve performansını değerlendirmek için kullanılmaktadır. Finansal performansın değerlendirilmesi için finansal analizin yapılması gerekmektedir. Basit olarak finansal analiz, bilanço ve gelir tablosunun çeşitli analiz yöntemleriyle analiz edilmesidir. Firmalar finansal planlama yapmadan önce geçmiş yılların finansal tablolarını analiz ederek mevcut finansal durumunu belirleyerek gelecekte hedeflere ulaşmak için ihtiyaç duyulan fonun tespit edilmesi sağlanır.

Bu çalışmada, toplam aktifleri her yıl artan ve küresel ekonomide önem kazanan sivil havacılık sektöründe faaliyet gösteren firmaların finansal performansı araştırılmaktadır. Firmaların finansal performansı borsadaki değerinide etkilemektedir (Hamadi ve Bassil, 2015: 598-601). Bu amaçla, Avrupa'da faaliyet gösteren en büyük 10 havayolu firmasının faaliyet oranlarının piyasa değeri üzerindeki etkisi analiz edilmektedir. Çalışmanın literatüre katkı sağlaması beklenmektedir.

\section{LITERATÜR}

Firmalar hedeflerine ulaşmak için varlıklarını verimli kullanmaktadır. Ayrıca firmalar finansal planlama yapmadan önce geçmiş yıllara ait mali tablo bilgilerini analiz ederek mevcut finansal durumlarını tespit ederler. Bu nedenle firmaların finansal performanslarının değerlendirilmesinde finansal analizin önemli bir yeri vardır (Bayburt, 2007: 578). Finansal analiz genellikle finansal tablolar analiz teknikleriyle yapılmaktadır. Oran analizi, firmaların en çok kullandıkları finansal tablolar analiz tekniklerinden biridir (Karadeniz, Koşan ve Kahiloğulları, 2014: 131).

Oran analizi finansal tablolardaki birbiriyle ilişkili olan hesaplar üzerinde çeşitli matematiksel oranlamalar yapılarak hesaplanmaktadır. Oran analizi likidite, faaliyet, finansal yapı ve karlılık oranları olmak üzere dört kategoride yapılmaktadır (Akdogan ve Tenker, 2007: 640). Firmaların likidite durumların değerlendirmek için likidite oranlarından yararlanılmaktadır. Firmalar kaynaklarının yapısını değerlendirmek için finansal yapı oranlarını kullanırlar. Finansal performansın değerlendirilmesinde karlılık oranları kullanılmaktadır. Faaliyet oranları firmaların faaliyetlerinin performanslarının değerlendirilmesinde kullanılmaktadır. Çünkü finansal ve operasyonel başarının değerlendirilmesinde faaliyet performansı oldukça önemlidir. Firmalar varlıklarını daha etkin kullandıkça verimlilikleri de artmaktadır. Bu yüzden firmaların varlıklarını etkin ve verimli kullanmaları önerilmektedir. 
Çalışmada faaliyet oranlarının firmaların piyasa değeri üzerine etkisi incelenmektedir. Havayolu firmalarının yüksek fiyatlı uçaklara sahip olması, firmaların toplam aktiflerinin yüksek tutarlarda olmasına neden olmaktadır. Havayolu firmalarının az sayıda uçağa sahip olması, finansal başarı elde edebilmeleri ve amaçlarına ulaşabilmeleri için varlıklarının etkin ve verimli kullanıımasını gerektirmektedir. Varlıkların etkin kullanılmaması, varlıkların azalmasına neden olabilmektedir. Çünkü havayolu firmalarının faaliyet kaldıracı ile yüksek tutarlarda marjinal kar elde edebilmektedir. Yüksek tutarlarda duran varlık satın almaları, kısa ve uzun vadeli borçlanmalarını artırmaktadır. Ancak düşük tutarlarda stok bulundurmaları, peşin veya kısa vadeli taksitlerle bilet satmaları, alacakları tahsili hızlandırmakta ve likiditeyi artırmaktadır. Firmaların varlıklarının etkin kullanılıp kullanılmadığını ölçmek için faaliyet oranları ile finansal durumlarının incelenmesi gerekmektedir. Bu çalışmada küresel ekonomide önemli bir sektör haline gelen ve her geçen yıl toplam aktifi büyüyen sivil havacılık sektöründe faaliyet gösteren firmaların performansları değerlendirilmektedir.

\section{LITERATÜR TARAMASI}

Havayollarının faaliyet oranları ile piyasa değeri arasındaki ilişki üzerine yapılan çalışmaların sayısı oldukça sınırıdır. Faaliyet oranlarının firma değeri üzerindeki etkisi ile ilgili çalışmaya literatürde rastlanılmamıştır. Bu nedenle havayolu şirketlerinin finansal ve operasyonel performansı ile oran analizi yöntemi üzerine yapılan çalışmalara değinilmektedir. Konuyla ilgili literatürdeki çalışmalar bu bölümde yer almaktadır.

Pineda vd. (2018), havayolu firmalarının finansal ve operasyonel performansını iyileştirmek için bir model önermektedir. MCDM, Veri Madenciliği ve DANP yöntemleri kullanılarak analiz yapılmıştır. Mevcut modelin havayolu firmalarının finansal verimliliğinin değerlendirilmesinde kullanılabileceği ifade edilmektedir. Dayı ve Ulusoy (2018), Dünyadaki 19 havayolu firmasının finansal performansını aktif devir hızı, alacak devir hızı, stok devir hızı oranları gibi çeşitli oranlar kullanarak değerlendirmiştir. Minimum Örten Ağaç yaklaşımı ile analiz yapılmıştır. Analiz sonuçlarına göre Türk Hava Yolları'nın karlıık, aktif ve satış gelirleri açısından yüksek performans gösterdiği ifade edilmektedir. Sakız ve Ünkaya (2018) havayolu firmalarının finansal ve faaliyet performanslarını değerlendirmek için Türk Hava Yollarının (THY) iflas riskini araştırmıştır. Hesaplanan tüm verilere göre şirketin iflas riski açısından çok iyi bir finansal duruma sahip olduğu belirtilmektedir. Seufert vd. (2017) dünyada faaliyet gösteren havayolu şirketlerinin 2007-2013 döneminin finansal ve faaliyet verimliliklerini sermaye, personel gibi değişkenleri kullanarak incelemiştir. Avrupalı havayolu firmalarının operasyonel verimlilik ve etkinlil açısından diğer havayolu firmalarından daha başarıı olduğunu ifade etmişlerdir.

Omrani ve Soltanzadeh (2016), havayolu firmalarının performanslarını değerlendirmek için NDEA (Network Data Envelopment Analysis) yöntemini İran havayolu şirketlerinde uygulamıştır. Analiz sonuçlarına göre verimliliğin daha düşük düzeyde olduğu tespit edilmiştir. Teker vd. (2016) yılında dünyada faaliyet gösteren 20 büyük havayolu firmasının finansal performansını değerlendirmiştir. Toplam gelir veya karlılığa dayalı finansal performans ölçümünün zayıf olduğu ve finansal olmayan göstergelerin de dâhil edilmesi ile değerlendirmenin genişletilebileceği belirtilmektedir. Saranga ve Nagpal (2016) operasyonel performansı etkinlik açısından 
Hindistan havayolu firmalarında değerlendirmiştir. Analiz sonuçlarına göre, bazı yapısal ve düzenleyici faktörlerin havayolu firmalarının performansı üzerinde istenmeyen bir etkisi olsada, Hindistan'daki düşük maliyetli taşıyıcılar önemli operasyonel verimlilik elde etmiştir. Miranda vd. (2016) düşük maliyet ve havayolu taşımacılı̆̆ına giriş engellerinin firmaların verimliliklerinin ölçülüp ölçülemeyeceğini araştırmıştır. Çok kriterli karar verme yöntemi kullanılarak yapılan çalışmada şirketlerin verimliliğinin ölçülebileceğini tespit etmişlerdir.

Wanke vd. (2015) Asya havayolu firmalarının faaliyet performansını değerlendirmek için TOPSIS ve MCMC lineer modeli kullanmıştır. Analiz sonuçları, maliyetler, sahiplik türü, pazar konumlandırmasının verimlilik açısından önemli olduğunu göstermektedir. Arjomandi ve Seufert (2014) 6 kıtada faaliyet gösteren 48 havayolu firmasının performansını 2007-2010 dönemi verilerini kullanarak karşılaştırmıştır. Çin ve Kuzey Asya'daki havayolu firmalarının teknik verimliliklerinin iyi olduğu ve Avrupa'daki birçok havayolu firmasının iyi çevresel performansa sahip olduğu ifade edilmektedir. Tretheway ve Markhvida (2014) havayolu firmalarının uzun dönemde finansal sürdürülebilirlik düzeylerini incelemektedir. Havayolu firmaları yüksek tutarlarda duran varlıklara ve maliyetlere sahiptirler. Analiz sonuçlarına göre firmaların marjinal maliyetleri azaltılmalı ve varlıkları etkin kullanılması önerilmektedir. Ömürbek ve Kınay (2013) Türkiye ve Almanya'da faaliyet gösteren birer havayolu firmasının performansını TOPSIS yöntemiyle incelemiştir. Bazı şirketlerin diğerlerinden daha iyi performans gösterdiği ifade edilmiştir.

Coli vd. (2011), Veri Zarflama Analizi ve Stokastik Sınır Analizi yöntemleriyle havayolu firmalarının verimliliklerini araştırmışlardır. Stokastik Sınır Analizi yöntemi, Veri Zarflama Analizi'den daha başarılı sonuçlar verdiği ifade edilmektedir. Assaf ve Josiassen (2011) İngiliz havayolu firmalarının performanslarını değerlendirmek için Veri Zarflama Analizi kullanmıştır. Çalışmada petrol fiyatlarındaki artışın ve piyasadaki rekabet düzeyi gibi faktörlerin potansiyel verimsizliğin belirleyicileri arasında olduğu belirtilmektedir. Malighetti vd. (2011), havayolu firmaları ile havalimanlarının değerini etkileyen faktörleri araştırmıştır. Uygulama dünyadaki 24 havaalanı ve 87 havayolunu firmasını içermektedir. Her ne kadar havayolu şirketlerinin yaşı ve rota sayısı piyasa değeri üzerinde olumsuz bir etkiye sahip olsa da, düşük maliyetli şirketlerin piyasa değeri diğerlerinden istatistiksel olarak daha yüksek olduğu ifade edilmiştir.

Homsombat vd. (2010) Kuzey Amerika'da faaliyet gösteren havayolu firmalarının finansal ve faaliyet performansını değerlendirmiştir. Havayolu firmalarının verimlilik düzeyleri, toplam verimlilik ve tüm ekonomik döngü açısından değerlendirilmektedir. Barros ve Peypoch (2009) Avrupa'da faaliyet gösteren havayolu firmalarının faaliyet performansını Veri Zarflama Analizi yöntemiyle incelemiştir. Regresyon analizi sonucunda, nüfusun ve uçuş ağlarının havayollarının etkinliğinde önemli bir rol oynadığı belirtilmektedir. Barbot ve Sochirca (2008), havayolu firmalarının verimlilikleri ile etkinlikleri arasındaki farkı araştırmaktadır. Analiz sonuçlarına göre, verimlilik ve etkinlik düzeyinin değerlendirilmesinde Veri Zarflama Analizinin kullanılmasının doğru olmadığı belirtilmektedir. Schefczyk (1993), 15 uluslararası havayolu firmasının operasyonel performansını Veri Zarflama Analizi ile araştırmaktadır. Analiz sonuçlarına göre büyük olan havayolu firmalarının operasyonel performanslarının ve karlılıklarının da yüksek olduğu belirtilmektedir. 


\section{MATERYAL VE YÖNTEM}

Çalışmanın amacı Avrupa'da faaliyet gösteren havayolu firmalarının faaliyet performanslarının piyasa değeri üzerine etkisini değerlendirmektir. Bu açıdan çalışma litertürde ilk kez yapılmaktadır. Firmaların faaliyet performanslarının firma değeri üzerine etkisinin incelenmesi ticari ve üretim işletmeleri üzerinde daha önce literatürde incelenmiştir. Faaliyet oranlarının firma değeri üzerine etkisini inceleyen çalışmalar havayolu firmaları üzerinde yapılmasının literatüre katkı sağlaması beklenmektedir. Bu nedenle Avrupa kıtasında faaliyet gösteren en büyük 10 havayolu firmasının 2010-2016 dönemi verileri kullanılmıştır. Avrupa'daki en büyük 10 havayolu firması çalışmanın örneklemini oluşturmaktadır. Havayolu firmalarının isimleri, faaliyet gösterdikleri ülkeler ve 2016 yılı verilerine göre yolcu sayıları Tablo 1'de verilmiştir (CNNTURK, 2019).

Tablo 1. Havayolu Firmalarının Listesi

\begin{tabular}{clcc}
\hline Sıra No & \multicolumn{1}{c}{ Havayolu Firması } & Ülke & $\begin{array}{c}\text { Yolcu Sayısı } \\
\text { (milyon) }\end{array}$ \\
\hline 1 & Lufthansa Grup (Lufthansa, Austrian, Swiss, Eurowings) & Almanya & 117,4 \\
\hline 2 & Ryanair & İngiltere & 101,4 \\
\hline 3 & IAG (British Airways, Iberia, Vueling, Aer Lingus) & Ingiltere - İspanya & 94,9 \\
\hline 4 & Air France - KLM (Air France, KLM, HOP Transavia) & Fransa & 87,4 \\
\hline 5 & Easyjet & İngiltere & 74,5 \\
\hline 6 & Türk Hava Yolları & Türkiye & 62,8 \\
\hline 7 & Aeroflot Grup (Aeroflot, Rossiya, Pobeda) & Rusya & 43,4 \\
\hline 8 & SAS Grup (Scandinavian Airlines) & İsveç & 29,4 \\
\hline 9 & Norveç Havayolları & Norveç & 29,3 \\
\hline 10 & Air Berlin Grup (Air Berlin, NIKI) & Almanya & 28,9 \\
\hline
\end{tabular}

Kaynak: https://www.cnnturk.com/dunya/avrupanin-en-buyuk-10-hava-yolu-sirketi?page=8

2016 yılı verilerine göre Lufthansa Grubu, Avrupa'da en yüksek yolcu taşıyan firma olarak 117.4 milyon yolcu taşımıştır. Ryanair ucuz fiyatlı bilet sattığından, 101.4 milyon yolcu taşıyarak Avrupa'da ikinci sırada yer almaktadır. Türk Hava Yolları 62.8 milyon yolcu taşıyarak ilk onda altıncı sırada yer almaktadır. SAS Grubu, Norveç Hava Yolları ve Air Berlin Grubu ilk onda en az yolcu taşıyan firmalardır. Air Berlin Grubu, 28.9 milyon yolcu ilk 10 'da en düşük yolcu sayısına sahiptir.

Havayolu firmalarının finansal verimliliğini değerlendiren aktif devir hızı, duran varlık devir hızı gibi birçok oran vardır. Ancak, firmaların faaliyet gösterdiği sektörlere uygun aktivite oranlarının kullanılması araştırmanın başarısı için hayati önem taşımaktadır. Dayı and Esmer (2017) havayolu firmalarının finansal performansın değerlendirilmesinde alacak devir hızı, stok devir hızı, net kar marjı, aktif karlılık oranı ve özsermaye karlılık oranlarını kullanmıştır. Havayolu firmalarının bilet satışları arttıkça satış gelirlerinin arttığı, satış gelirlerinin artmasıyla alacakların arttığı ifade edilmektedir. Havayolu firmalarının stokları her geçen yıl düşmektedir. Bu sebeplerden dolayı yukarıda verilen değişkenlerin havayolu firmalarının finansal verimliliklerinin değerlendirilmesinde önemli olduğu ifade edilmektedir. Diğer çalışmalardan farklı olarak, bu çalışmada en çok kullanılan aktivite oranlarından bir model oluşturulmuştur. Bu nedenle, çalışmada havayolu firmalarının 
faaliyetleri hakkında bilgi sağlayan oranlar kullanılarak model oluşturulmuştur. Modelde yer alan değişkenlerin kodları, veri türleri, frekansları ve veri kaynaklarını içeren bilgiler Tablo 2'de verilmiştir.

Tablo 2. Değişkenler ve Veri Seti

\begin{tabular}{lcccc}
\hline Değişkenler & Kod & Tür & Frekans & Veri Kaynağı \\
\hline Fiyat & P & Bağımlı & Günlük & Yahoo Finance \\
\hline Aktif Devir Hızı & AT & Bağımsız & Yılık & Finansal Tablolar \\
\hline Alacak Devir Hızı & ART & Bağımsız & Yıllık & Finansal Tablolar \\
\hline Stok Devir Hızı & IT & Bağımsız & Yıllık & Finansal Tablolar \\
\hline Finansal Kaldıraç & FL & Bağımsız & Yılık & Finansal Tablolar \\
\hline
\end{tabular}

Çalışmada 2008-2016 dönemi verileri kullanılmak istenmiş, ancak mali tablolar 2008 yılında yaşanan küresel finansal krizden olumsuz etkileneceğinden, 2009 yılı verileri kullanılmamıştır. Çünkü Işık ve Kiracı (2012), 2008 krizinin firmaların faaliyetlerini ve çalışma sermayesi unsurlarını etkilediğini ifade etmektedir. Bu nedenle çalışmanın veri seti 2010-2016 dönemini içermektedir. Aktif devir hızı, alacak devir hızı, stok devir hızı ve finansal kaldıraç oranı bağımsız denetimden geçmiş finansal tablo verilerinden hesaplanmıştır. Hisse senedi fiyatı değişkeni olarak yılın son işlem günü borsa kapanış fiyatı alınmıştır. Firmanın değeri borsada işlem gördüğü yılın son seansındaki kapanış fiyatı esas alınarak hesaplanmıştır. Havayolu firmaları varlıklarını verimli kullandıkça finansal performansları artmaktadır. Böylece finansal performansın artmasıyla firmaların değerinin artması beklenmektedir.

Aktif devir hızı oranı, net satışların aktif toplamına bölünmesiyle hesaplanmaktadır. Firmaların varlıklarının verimli kullanılma durumunu göstermektedir. Aktif devir hızı oranı ne kadar yüksek olursa firmaların varlıklarını o kadar verimli kullandığını ifade edilmektedir. Firmaların düşük aktif ile verimliliklerini artırmaları önerilmektedir. Alacak devir hızı oranı, net satışların ticari alacakları kaç kez karşıladığını göstermektedir. Alacak devir hızı oranının yüksek olması, alacakların tahsil gücünün yüksek olduğu anlamına gelmektedir. Alacakların tahsil süresi nakit akışında önemlidir. Alacaklar ne kadar geç tahsil edilirse, firmaların nakit sıkıntısı yaşama ihtimali artabilir. Firmaların alacaklarını azaltarak, alacak devir hızı oranının yüksek olması beklenmektedir. Stok devir hızı oranı, stokların bir yıl içerisinde kaç kez döndüğünü göstermektedir. Stok devir hızı oranının yüksek olması, firmaların stoklarını kısa sürede nakde veya alacağa dönüştürdüğü anlamına gelmektedir. Havayolu firmalarının stok tutarları düşük olduğundan oranın çok yüksek olması beklenmemektedir. Alacakların ortalama tahsil süresi ve stokların devir süresi değişkenlerinin, alacak devir hızı oranı ve stok devir hızı oranı değişkenleri arasında yüksek korelasyon ilişkisi olacağından analize dâhil edilmemiştir. Finansal kaldıraç oranı ile karlılık arasında anlamlı bir ilişki olduğu ifade edilmektedir (Çakır ve Küçükkaplan, 2012, s. 81). Finansal kaldıraç oranı, firmaların varlıklarının verimliliklerinin değerlendirilmesinde kullanılan önemli bir göstergedir. Firmaların borçları arttıkça, faiz ödemesinin tutarıda artmaktadır. Giderlerin artması, gelirleri azaltmaktadır. Bu nedenle borçlanmanın finansal performansını değerlendirmek için finansal kaldıraç oranı modelde kullanılmaktadır. 
Panel veri, hane, şirket, ülke gibi birden fazla yatay kesit ile birden fazla zaman kesitinin birleşmesinden oluşmaktadır (Baltagi, 2005: 1). Yatay ve dikey kesitin birden fazla olması panel veri analizini gerektirmektedir. Çünkü zaman serilerinde birden fazla yatay kesitin olması durumunda, panel veri analizi dışında herhangi bir ekonometrik yöntemin kullanılması mümkün değildir. Panel veri regresyon analizinde kullanılan formül aşağıda verilmektedir (Baltagi, 2005: 11):

$$
y_{i t}=\alpha+X^{\prime}{ }_{i t} \beta+u_{i t} \quad i=1, \ldots \ldots N ; t=1, \ldots \ldots T
$$

$\boldsymbol{i}$ firma sayısını, $\boldsymbol{t}$ zaman serisini, $\boldsymbol{u}_{\boldsymbol{i}}$ hata katsayısını, $\boldsymbol{\alpha}$ sabit sayıyı, $\boldsymbol{X}^{\prime}{ }_{i \boldsymbol{t}}$, it'lerin gözlem sayısını ve $\boldsymbol{\beta}$ açıklayıcı değişkenlerin katsayısını ifade etmektedir (Guris, 2018: 7). Panel veri analizinde birden fazla yöntem mevcut olup sabit etkiler, rassal etkiler, havuzlanmış regresyon yöntemi ve rassal parametreler yöntemleri en çok kullanılanlardır (Green, 2010: 386-387). Ayrıca dengeli ve dengesiz panel veri modelleri de vardır (Baum, 2006: 46-51). Data setinde yatay kesitte bazı yıllarda eksik veri olması durumunda dengesiz panel veri analizi yapılmaktadır (Tatoglu, 2013: 1). Panel veri analizinde hangi yöntemi kullanılacağına karar vermek için Hausman testi yapılmaktadır. Hausman testi panel veri analizinde hangi tahmincilerin kullanılacağına karar vermek için kullanılmaktadır (Tatoglu, 2018: 184). Uygulamada bir şirketin 2010 yılından sonra borsada işlem görmesinden dolayı bağımlı değişken de birkaç yıllık veri eksik olduğundan, dengesiz panel veri yöntemiyle analiz yapılmıştır. Çalışmanın modeli aşağıda verilmiştir:

$$
P_{i t}=\alpha+\beta_{1} A T_{i t}+\beta_{2} A R T_{i t}+\beta_{3} I T_{i t}+\beta_{4} F L_{i t}+u_{i t}
$$

Hisse senedi fiyatı bağımlı değişken, aktif devir hızı, alacak devir hızı, stok devir hızı ve finansal kaldıraç oranı bağımsız değişken olarak modelde yer almaktadır. Hisse senetlerinin fiyatlarındaki farklılık modeli anlamsız etkileyebileceğinden hisse senedi fiyatlarının logaritmaları alınmıştır. Model daha önce kullanılmadığı için literatüre katkı sağlaması beklenmektedir.

\section{BULGULAR}

Bu kısımda değişkenlerin tanımlayıcı istatistikleri ilk olarak verilmektedir. Hausman testi, Breusch Pagan testi ve panel veri rassal etkiler yöntemi analiz sonuçlarına sonraki kısımda yer verilmektedir. Modelde yer alan değişkenlerin tanımlayıcı istatistikleri Tablo 3’de verilmiştir.

Tablo 3. Modelin Tanımlayıcı İstatistikleri

\begin{tabular}{lcccc}
\hline Değişkenler & Ortalama & Standart Sapma & Minimum & Maksimum \\
\hline Fiyat & 1.453582 & 0.985934 & 0.23 & 3.24 \\
\hline Aktif Devir Hızı & 67.287030 & 554.4649 & 0.395 & 4.640 \\
\hline Alacak Devir Hızı & 19.906110 & 21.26943 & 3.67 & 99.015 \\
\hline Stok Devir Hızı & 69.743970 & 57.46578 & 8.0695 & 288.945 \\
\hline Finansal Kaldıraç & 0.779597 & 0.242732 & 0.4344 & 2.0666 \\
\hline
\end{tabular}


Firmaların hisse senetlerinin fiyatları 0,23 ile 3.24 arasında değişmektedir. Aktif devir hızı 0.395 ile 4.640; alacak devir hızı 3.67 ile 99.015 arasında; stok devir hızı 8.06 ile 288.94 arasında ve finansal kaldıraç oranı 0.43 ile 2.06 arasında değişim göstermektedir. Hisse senedinin fiyat ortalaması ise 1,45'dir. Değerin düşük olmasının sebebi hisse senedi fiyatının logaritmasının alınmasıdır. Eğer hisse senedinin fiyatının logaritması alınmazsa, model olumsuz etkilenebilmektedir. Faaliyet oranlarının değişim aralıklarının yüksek olduğu görülmektedir. Modeldeki aktif devir hızı yüksektir. Varlıkların verimli kullanıldığı düşünülmektedir. Varlıkların verimli kullanılmasıyla likidite ve karlılığın da artması beklenmektedir. Alacak devir hızı düşüktür. Oranın yüksek olması beklenmektedir. Alacakların devir hızının yüksek olması, firmanın nakit varlıklarının artmasını sağlamaktadır. Stok devir hızı ortalaması normal görülmektedir. Çünkü havayolu şirketleri hizmet işletmesi olduğundan yüksek tutarlarda stok bulundurması beklenmemektedir. Finansal kaldıraç oranı 0,43 ila 2,06 arasında değişmektedir. Özkaynaklarından daha yüksek tutarlarda borçları olan firmalar vardır. Borçlanma arttıkça, ödenecek faiz giderleri de artmaktadır. Borçların artması finansal riskide artırabilmektedir.

Panel veri analizinde sabit etkiler veya rassal etkiler yöntemlerinden hangisinin kullanılacağına karar vermek için Hausman Testi yapılmaktadır. Hausman Testi sonuçları Tablo 4'de verilmiştir.

Tablo 4. Hausman Testi Sonuçları

\begin{tabular}{lcccc}
\hline & (b) Sabit Etkiler & (B) Rassal Etkiler & b-B & S.E. \\
\hline Aktif Devir Hızı & .0002204 & .0002336 & -.0000132 & .0000234 \\
\hline Alacak Devir Hızı & .0126165 & .0137277 & -.0011112 & .0018362 \\
\hline Stok Devir Hızı & -.0017042 & -.0018660 & .0001618 & .0003165 \\
\hline Finansal Kaldıraç & -.5127839 & -.5268744 & .0140905 & .0301479 \\
\hline Prob >chi2 $=0,9762$ & & & & \\
\hline
\end{tabular}

Hausman Testi sonuçları incelendiğinde Prob değeri > 0,05 üzerinde olduğundan sabit etkiler yöntemini iddia eden (sıfır hipotezi) hipotez reddedilerek, alternatif hipotez (rassal etkiler yöntemi) kabul edilmektedir. Hausman Testi sonucuna göre rassal etkiler yönteminin kullanılması gerekmektedir. Ancak rassal etkiler yöntemiyle havuzlanmış en küçük kareler yönteminden hangisinin kullanılacağına karar vermek için BreuschPagan Testi yapılmaktadır. Breusch-Pagan Testi sonuçları Tablo 5' de verilmiştir.

Tablo 5. Breusch-Pagan Testi Sonuçları

\begin{tabular}{lcc}
\hline & Var & st $=$ sqrt(var) \\
\hline Fiyat & .9720658 & .985934 \\
\hline $\mathrm{e}$ & .0330350 & .1817555 \\
\hline $\mathrm{u}$ & .8496049 & .9217401 \\
\hline & & chibar2(01) $=147.38$ \\
\hline
\end{tabular}


Breusch-Pagan Testi sonuçları incelendiğinde, Prob<0,05'den küçük olduğunda rassal etkiler yöntemi kullanılmaktadır. Analiz sonuçlarına göre $p=0,000$ olduğundan, rassal etkiler yöntemi tercih edilmiştir. Panel veri rassal etkiler yöntemi ile yapılan analizin sonuçları Tablo 6’da verilmiştir.

Tablo 6. Panel Veri Rassal Etkiler Modeli Analiz Sonuçları

\begin{tabular}{lcccc}
\hline $\begin{array}{l}\text { Gözlem sayısı=67 } \\
\text { Grup sayısı=10 }\end{array}$ & R-sq: 0,4352 & \multicolumn{2}{c}{ Wald chi2(5) $=28.71$ Prob $>$ Chi2=0.0000 } \\
\hline Fiyat & Katsayı & Standart Sapma & $\mathbf{z}$ & P>z \\
\hline Aktif Devir Hızı & .0002336 & .0000631 & 3.70 & 0.000 \\
\hline Alacak Devir Hızı & .0137277 & .0042071 & 3.26 & 0.001 \\
\hline Stok Devir Hızı & -.0018660 & .0008478 & -2.20 & 0.028 \\
\hline Finansal Kaldıraç & -.5268744 & .1319500 & -3.99 & 0.000 \\
\hline Sürekli & 1.7172740 & .3117933 & 5.51 & 0.000 \\
\hline
\end{tabular}

Analiz sonuçları modelin ve değiş̧kenlerin anlamlı olduğunu göstermektedir. Modelin açıklama gücü \%43,52'dir. Aktif devir hızı varlıkların verimliliğini göstermektedir. Firma varlıklarını verimli ve etkin kullanması durumunda daha çok satış yapmakta, karı ve karlılı̆ı artmaktadır. Böylece firmanın piyasa değerinin de artması beklenmektedir. Analiz sonuçlarına göre aktif devir hızı ile hisse senedi fiyatı arasında pozitif yönlü bir ilişki vardır. Literatürde yapılmış bir çalışmada, Ayrıçay ve Türk (2014), aktif devir hızı ile firma değeri arasında anlamlı bir ilişki bulmuştur. Karaca ve Başcı (2011) aktif devir hızı oranının firma değerini olumlu yönde etkilediğini ifade etmiştir. Firmalar varlıklarını verimli kullandıkça satışlarının ve karlarının artması beklenmektedir. Firmaların karları artınca özkaynaklarıda yükselmektedir. Hissedarlar firmanın karının arttığını görünce firmanın finansal durumunu başarılı olarak değerlendirerek hisse senedi satın almak isteyecektir. Hisse senedine talep arttıkça, fiyatlar yükselecektir. Böylece firmanın borsa değeride yükselmiş olacaktır.

Firmaların alacaklarını tahsil gücü arttıkça likiditesi artmaktadır. Likiditesi yüksek olan firmaların piyasa değeri yükselebilmektedir. Alacak devir oranı ile hisse senedi değeri arasında pozitif yönlü ilişki vardır. Alacakların tahsil edilmesinin firmanın değerini \%1,3 oranında etkilediği görülmektedir. Alacakların tahsil gücü \%1,3 oranında arttığında, hisse senedinin fiyatı \%1 oranında artmaktadır. Alacakların tahsil süresinin kısalması, firmanın likiditesini yükseltmektedir. Likiditenin artmasıyla firmanın finansal durumunun olumlu yönde etkilenmesi beklenmektedir.

Stok, ticari işletmelerde önemli bir aktif hesap kalemi olduğundan, stok devir hızı ticari işletmelerin stoklarının devir hızının tespitinde önemli bir göstergedir. Ancak havayolu firmaları hizmet işletmesi olduklarından, ticari işletmelerde olduğu gibi yüksek tutarlarda stok bulundurmazlar. Analiz sonuçları bu durumu doğrulamakta ve stok devir hızı ile firma değeri arasında negatif yönde bir ilişki vardır. Analiz sonucunda elde edilen katsayı \%1'den azdır. Stoklar çalışma sermayesi içinde önemli bir hesap olsada, stoklar havayolu firmalarında anlamlı olmayabilir. Uluyol ve Türk (2013) stok devir hızının üretim işletmelerinin firma değeri üzerinde etkisini incelemiştir. Bir hizmet işletmesi olan havayolu firmalarında ise stok devir hızıyla firma değeri arasında negatif yönde anlamlı bir ilişki söz konusudur. 
Finansal kaldıraç oranı firmaların varlıklarının ne kadarını borç ile finanse ettiklerini göstermektedir. Borcun artmasıyla, firmanın değeri optimum sermayeye ulaşıncaya kadar artmaktadır. Borcun kaldıraç etkisi firma değerini etkileyebileceğinden modelde yer almaktadır. Analiz sonuçlarına göre havayolu firmaları ile finansal kaldıraç oranı arasında negatif yönlü bir ilişki söz konusudur. Finansal kaldıraç oranı arttıkça, firmaların piyasa değeri \%52 oranında azalmakta veya finansal kaldıraç oranı azaldıkça firmanın değeri \%52 oranında artmaktadır. Firmalar gerektiğinde borçlandığında, sermaye maliyeti artabilir. Bu yüzden firmanın değeri bu durumdan negatif etkilenebilmektedir. Havayolu firmalarının borçlanma eğiliminde oldukları gözlemlenmektedir. Bu durumun firmanın değerini negatif etkileyebileceği düşünülmektedir.

\section{SONUÇ ve TARTIŞMA}

Faaliyet devir hızları firmaların faaliyetlerinin verimliliğinin değerlendirilmesinde kullanılmaktadır. Faaliyet devir hızları, firmanın faaliyet performansını etkilediği gibi firma değerini de etkilemektedir. Faaliyet oranları sadece firmanın performansını değil aynı zamanda değerini de etkilemektedir. Az maliyet ile daha yüksek tutarlarda satış yapmak, alacakları kısa sürede tahsil ederek likiditeye çevirmek, stokları kısa sürede döndürmek ve borçlardaki artış ile finansal kaldıraç etkisinden yararlanmak firmaların karını ve karlılı̆ının artırabilmektedir. Karın artması firmanın piyasa değerini etkilemektedir. Bu çalışmada faaliyet devir hızı sayıları yüksek olan havayolu firmalarının faaliyet devir oranlarının firma değeri üzerine etkisi incelenmiştir.

Aktif devir hızı varlıkların verimliliğini göstermektedir. Aktif devir hızı ne kadar artarsa, firmanın varlıkları etkin kullanması da o kadar artmaktadır. Analiz sonuçlarına göre aktif devir hızı ile hisse senedi fiyatı arasında pozitif yönlü bir ilişki vardır. Aktif devir hızı ile hisse senedi arasında ki katsayı düşüktür. Firmaların alacaklarını tahsil gücü arttıkça likiditesi artmaktadır. Firmaların alacaklarını tahsil etmesi, hisse senedinin fiyatının artmasında etkili olabilmektedir. Alacak devir oranı ile hisse senedi değeri arasında pozitif yönlü ilişki vardır. Alacakların tahsil edilmesinin firmanın değerini \%1,3 oranında etkilediği görülmektedir. Alacakların tahsil süresinin düşmesi firmanın değerinin pozitif yönde etkilendiğini göstermektedir. Alacakların tahsil süresi kısaldıkça daha çok gelir elde edilmekte ve karlıık artmaktadır. Stok devir hızı da firmaların performansları için önemlidir. Stok devir hızı ile firma değeri arasında negatif yönde bir ilişki vardır. Havayolu şirketlerinin stoklarının az olması bu durumu doğrulamaktadır. Analiz sonuçlarına göre havayolu firmaları ile finansal kaldıraç oranı arasında negatif yönlü bir ilişki söz konusudur. Finansal kaldıraç oranı \%1 arttıkça, firmaların piyasa değeri \%52 oranında azalmaktadır. Finansal kaldıraç firmaların piyasa değerini negatif yönde etkilemektedir.

Havayolu firmalarının yüksek tutarlarda sabit sermaye yatırımı olması, varlıkların verimli kullanılmasını düşürebilmektedir. Uçakların fiyatları pahali ve havayolu firmalarının büyümeleri için çok sayıda uçağa sahip olmalıdırılar. Havayolu firmalarının sınırlı sayıda uçak ile yüksek sayıda yolcu taşımaları faaliyetlerinin verimliliğini olumlu yönde etkilemektedir. Ancak firmaların büyümeleri durumunda verimliliklerini artırmaları önerilmektedir. Ayrıca çalışma sermayesi unsurlarının etkin kullanılması firmanın piyasa değerini etkileyeceği düşünülmektedir. Bu nedenle havayolu firmalarının çalışma sermayesinin firma değeri üzerine etkisinin incelenmesi tavsiye edilmektedir. 


\section{ETiK BEYANI}

Makalelerde aşağıda belirtilen metindeki kurallara uyulmalı ve aşağıdaki metne benzer bir metin etik metni başlığı altında makaleye eklenmelidir.

"Bu makalede dergi yazım kurallarına, yayın ilkelerine, araştırma ve yayın etiği kurallarına, dergi etik kurallarına uyulmuştur. Makale ile ilgili doğabilecek her türlü ihlallerde sorumluluk yazar(lar)a aittir."

\section{KAYNAKÇA}

Aeroflot Group. (2018). Reporting. https://ir.aeroflot.com/shareholders-and-investors/, Accessed 10 Dec 2018. Air Berlin Group. (2018). Investor Relations. http://ir.airberlin.com/en/ir. Accessed 10 Dec 2018.

Air France KLM. (2018). Investor Relations. https://www.airfranceklm.com/en/profil/analyst-investor. Accessed 10 Dec 2018.

Akdoğan, N. ve Tenker, N. (2007). Finansal Tablolar ve Mali Analiz Teknikleri. Ankara: Gazi Kitabevi.

Assaf, A. G. ve Josiassen, A. (2011). The operational performance of UK airlines: 2002-2007. Journal of Economic Studies, 38(1), 5-16.

Arjomandi, A. ve Seufert, J. H. (2014). An Evaluation of the World's Major Airlines' Technical and Environment Performance. Economic Modelling, 41, 133-144.

Ayrıçay, Y., ve Türk, V. E. (2014). Finansal Oranlar Ve Firma Değeri ilişkisi: BisT'de Bir Uygulama. Muhasebe ve Finansman Dergisi, (64), 53-70.

Baltagi, B. H. (2005). Econometric analysis of panel data (Third Edition). England: John Wiley\&Sons, Ltd.

Barbot, C. Costa, A. ve Sochirca, E. (2008). Airline Performance in the new market context: A Comprative Productivty and Efficiency Analysis. Journal of Air Transport Management, 14, 270-274.

Barros, C. P. ve Peypoch, N. (2009). An evaluation of European airlines' operational performance. International Journal of Production Economics, 122(2), 525-533.

Bartz-Zuccala, W., Mohren, P. ve Schweiger, H. (2018). The role of innovation and management practices in determining firm productivity. Comparative Economic Studies, 60 (4), 502-530.

Baum, C. F. (2006). An Introduction to Modern Econometrics Using Stata. Texas: A Stata Press Publication.

Bayburt, N. (2007). İşletmelerde Performans Değerlendirmenin Önemi ve Performans Göstergeleri Arasındaki İlişkiler. Sosyal Siyaset Konferansları Dergisi, 53, 577-592.

Çakır, H. M. ve Küçükkaplan, i̇. (2012). İşletme Sermayesi Unsurlarının Firma Değeri ve Karlılığı Üzerindeki Etkisinin IMKB'de İşlem Gören Üretim Firmalarında 2000-2009 Dönemi İçin Analizi. Muhasebe ve Finansman Dergisi, (53), 69-86.

Coli, M., Nissi, E. ve Raposelli, A. (2011). Efficiency Evaluation in an Airline Company: Some Empirical Results, Journal of Applied Sciences, 11(4), 737-742.

CNN TURK. (2019). İşte Avrupa'nın En Büyük 10 Havayolu Şirketi. https://www.cnnturk.com/dunya/avrupaninen-buyuk-10-hava-yolu-sirketi?page=1. Accessed 10 May 2019. 
Dayı, F. ve Esmer, Y. (2017). Measuring Financial Performance of Airline Passenger Transport Company in European. 33rd International Academic Conference (s.60-71). Vienna: IISES, DOI: 10.20472/IAC.2017.33.008.

Dayı, F. ve Ulusoy, T. (2018). Evaluating Financial Performance with Minimum Spanning Tree Aprroach: An Application in Airlines Companies. Turkish Studies, 13(30), 89-103.

Easyjet. (2018). Investors .http://corporate.easyjet.com/investors. Accessed 10 Dec 2018.

Filer, R. K., Hanousek, J. ve Campos, N.F. (2000). Do Stock Markets Promote Economic Growth?, CERGE-EI Working Paper No.151. Available at SSRN: https://ssrn.com/abstract=1535900 or http://dx.doi.org/10.2139/ssrn.1535900

Green, W. H. (2010). Econometric Analysis. England: Pearson Education Limited.

Guris, S. (2018). Uygulamalı Panel Veri Ekonometrisi. İstanbul: Der Kitabevi Yayınevi.

Hamadi, H. ve Bassil, C. (2015). Financial Development and Economic Growth in the MENA Region. Comparative Economic Studies, 57, pp.598-622.

Homsombat, W., Fu, X. ve Sumalee, A. (2010). Policy Implications of Airline Performance Indicators Analysis of Major North American Airlines. Transportation Research Record: Journal of the Transportation Research Board, 2177(1), 41-48.

IAG. (2018). Investor Relation. http://www.iagshares.com/phoenix.zhtml?c=240949\&p=irol-irhome. Accessed 10 Dec 2018.

Işık, E. ve Kiracı, M. (2012). 2008 Küresel Finansal Krizin İşletmelerin Çalışma Sermayeleri Üzerindeki Etkilerinin Oranlar Aracılığıyla Tespiti: IMKB'de Bir Araştırma. Muhasebe ve Finansman Dergisi, 54, 157-174.

Karaca, S. S. ve Başçı, E. S. (2011). Hisse Senedi Performansını Etkileyen Rasyolar ve İKB 30 Endeksinde 20012009 Dönemi Panel Veri Analizi. Süleyman Demirel Üniversitesi iktisadi ve Idari Bilimler Fakültesi Dergisi, 16(3), 337-347.

Karadeniz, E., Kosan, L. ve Kahiloğullari, S. (2014). Borsa İstanbul'da İşlem Gören Spor Şirketlerinin Finansal Performansinin Oran Yöntemiyle Analizi. Çukurova Üniversitesi Sosyal Bilimler Enstitüsü Dergisi, 23(2), 129-144.

Lufthansa. (2018). Investor Relations. https://investor-relations.lufthansagroup.com/en/investorrelations.html. Accessed 10 Dec 2018.

Malighetti, P., Meoli, M., Paleari, S., and Redondi, R. (2011). Value determinants in the aviation industry. Transportation Research Part E, 47, 359-370.

Miranda, M., Baltazar, M.E. and Silva, J. (2016). Airlines Performance and Efficiency Evaluation using a MCDA Methodology. The Case for Low Cost Carriers vs Legacy Carriers. Open Eng., 6, 389-396.

Norwegian. (2018). Investor Relations. https://www.norwegian.com/ie/about/company/investor-relations/. Accessed 10 Dec 2018.

Omrani, H., and Soltanzadeh, E. (2016). Dynamic DEA models with network structure: An application for Iranian airlines. Journal of Air Transport Management, 57, 52-61. 
Ömürbek, V. ve Kınay, B. (2013). Havayolu Taşımacılığı Sektöründe TOPSıS Yöntemiyle Finansal Performans Değerlemesi. Süleyman Demirel Üniversitesi İtisadi ve Idari Bilimler Fakültesi Dergisi, 18(3), 343-363.

Pineda P. J. G.,Liou, J. J.H., Hsu, C. H. ve Chuang, C. Y. (2018). An Integrated MCDM model dor improving airline operational and financial performance. Journal of Air Transport Management, 68, 103-117.

Ryanair. (2018). Investor Relations. https://investor.ryanair.com/. Accessed 10 Dec 2018.

Sakız, B., ve Unkaya, G. (2018). Havayolu Taşımacılığı Sektöründe İflas Riski Yapay Sinir Ağları ile Airscore Tahmini. Marmara Universitesi Öneri Dergisi, 13(50), 150-172.

Saranga, H. ve Nagpal, R. (2016). Drivers of operational efficiency and its impact on market performance in the Indian Airline industry. Journal of Air Transport Management, 53, 165-176.

SAS Group. (2018). Investor Relations. https://www.sasgroup.net/en/category/investor-relations/. Accessed 10 Dec 2018.

Seufert, J. H., Arjomandi, A. ve Dakpo, K. H. (2017). Evaluating Operational Performance: A Leunberger-HicksMoorsteen Productivity Indicator. Transportation Research Part E: Logistics and Transportation Review, 104, 52-68.

Schefczyk, M. (1993). Operational Performance of Airlines: An Extension of Traditional Measurement Paradigms. Strategic Management Journal, 14(4), 301-317.

Tatoglu, F. Y. (2013). Ileri Panel Veri Analizi. İstanbul: Beta Basim Yayin Dagitim.

Tatoglu, F. Y. (2018). Panel Veri Ekonometrisi. İstanbul: Beta Basim Yayin Dagitim.

Teker, S., Teker, D. ve Guner, A. (2016). Financial Performance of Top 20 Airlines. Procedia - Social and Behavioral Sciences, 235, 603-610.

Tretheway, M. W. ve Markhvida, K. (2014). The aviation value chain: Economic returns and policy issues. Journal of Air Transport Management, 41, 3-16.

Türk Hava Yolları. (2018). Investor Relations. http://investor.turkishairlines.com/tr. Accessed 10 Dec 2018.

Uluyol, O., ve Türk, V. E. (2013). Finansal Rasyolarin Firma Değerine Etkisi: Borsa İstanbul (BiST)'da Bir Uygulama. Afyon Kocatepe Üniversitesi Iktisadi ve Idari Bilimler Fakültesi Dergisi, 15(2), 365-384.

Yahoo Finance. (2018). https://finance.yahoo.com/. Accessed 10 Dec 2018.

Wanke, P., Barros, C. P. ve Chen, Z. (2015). An Analysis of Asian Airlines Efficieny with two-stage TOPSIS and MCMC Generalized Linear Mixed Models. Int. J. Production Economics, 169, 110-126. 